\title{
Service Quality and Customers' Trust, Moderating Role of Personality Traits
}

\author{
Muhammad Ahmad ur Rehman, Amran Rasli* \\ Faculty of Management, Universiti Teknologi Malaysia, 81310 UTM Johor Bahru, Johor, Malaysia \\ *Corresponding author: m-amran@utm.my
}

\begin{abstract}
Customers' trust is an inevitable asset for organizations. The long-term relationship of customer-organization depends upon the presence of customers' trust on the organization. It's a delicate sense of feeling derived from quality and commitment of the organizations to meet customers' expectations. The significance of this phenomenon in services industry becomes even more critical where organizations have to know individual as well as contextual factors that influence on customers' trust. This study tested the impact of different dimensions of perceived service quality on customers' trust and how this perception varies depending upon the personality disposition in life insurance sector of Pakistan. Using cross sectional research design, the study taped customers' responses regarding service quality, customers' trust, and their personality disposition. The sample was obtained from insurance sector in different cities of Pakistan, where 242 customers were participated in the survey Explanatory factor analysis, single mean T-test, correlation and hierarchical multiple regression analyses were used to test proposed hypotheses. The results indicate positive relationship between different dimensions of service quality and customers' trust. The finding of moderation analysis shows that customer's personality traits have varied effects on the relationships between dimensions of service quality and customers' trust. Finally, based on quantitative findings, proposed framework was revised. This study recommends several implications for managers of services industry so that they should develop an effective service design to build long-term customers' trust in accordance with different personality traits.
\end{abstract}

Keywords: Dimensions of service quality, customers' trust, personality traits, insurance sector of Pakistan

(C) 2016 Penerbit UTM Press. All rights reserved

\subsection{INTRODUCTION}

Organizations survive in the market on the basis of their ability to fulfill customers' needs. Customers become satisfied when they get what they expect and start trusting the organizations (Rust et al., 2004; Rust et al., 2002) and will switch to other alternatives when they are not satisfied. This is a critical situation for the organizations when they fail to offer their customers what they demanded. The researcher believes that in today's highly competitive and globalized business environment, each customer is very important and adding profits to the overall growth of the organization. This not only reduces customer base but also shatters customers' trust, which damages organizations' image and leave long lasting devastating effects such as reputation and good will.

Customers' trust on an organization plays a vital role in bringing the customer for repeat purchases and generating positive word of mouth as well as in building long term relationship with the organization. Customers' trust in service industry is an complex phenomenon due to the challenging characteristics of services. Services are simultaneously produced and consumed (Zeithaml et al., 1985; Onkvisit \& Shaw, 1991) and service delivery is highly variable (Zeithaml et al., 1985). Services are neither stored nor carried out for future time period (Rathmell, 1966). Services are time dependent which makes it perishable (Onkvisit \& Shaw, 1991). Understanding about the perception of services by consumer, is difficult to understand due to intangibility (Zeithaml et al., 1981).

The unique nature of services tagged with characteristics such as intangibility, perishability, empathy, prompt responsiveness, assurance and their delivery determine the level of quality perceived by the customers, which further generates customers' trust. Zeithaml et al. (1996) and Eisingerich and Bell (2008) found strong relationship between perceived service quality and image of the service provider and trust and are the prerequisite for development of customers' trust (Moorman et al., 1992). Service quality that matches customer expectations generates trust and satisfaction in customer (Chiou \& Droge 2006). Service quality is the mean of differentiation for the firm (Gronroos, 1983; Parasuraman et al., 1988; Heskett et al., 1994; Rust \& Oliver, 1994; Zeithaml et al., 1996; Rust et al., 2002; Eisingerich \& Bell, 2008).

The extant literature has abundant of references showing positive impact of perceived service quality in generating customers' trust, however in all of those studies, service quality as a single construct has been considered. The SERVQUAL framework has consistently demonstrated the importance of service reliability in affecting overall service evaluations (Parasuraman et al., 1991b; Berry \& Parasuraman, 1991). The positive and significant impact of customer perceptions of service reliability on their overall service evaluations has also been shown by other marketers (Johnson \& Lars, 2001). Though the impact of perceived service quality on customers' trust has widely been researched, however detailed study of the impact of individual dimensions of perceived service quality on customers' trust is missing in current stream of literature. Based on Nordic model Gronroos (1990) gave two dimensions of service quality i.e. technical quality and functional quality whereas five dimensions of service had been identified by Parasuraman et al., (1988) which are reliability, 
assurance, responsiveness, empathy and tangibility. Each dimension plays a critical role in building overall perception about service quality. This study will explore the relative importance of each dimension in building customers' trust in insurance sector of Pakistan.

The nature of services owing to its certain characteristics requires unique and individualized treatment. Different customers may have different experience of the same service and hence may perceive quality of the service differently. Every customer may attach differing significance to different dimensions owing to differences in personality dispositions.

Personality has long been used in consumer research as a predictor of behavior. Scholars point to the utility of personality in explaining differences in response (e.g., attitudes) over and above the use of group-level (i.e., demographic) characteristics or purchase patterns (Endler \& Rosenstein, 1997, Fleeson, 2004, Funder \& Colvin, 1991, Lin, 2010). Individual behavior is derived from its personality i.e. the actions of an individual is the reflection of its personality (Fleeson, 2001) and directs different aspects of consumer behavior (Solomon, 2002; Funder \& Colvin, 1991).

Over the years, a greater number of the studies in the areas of perceived service quality, customers' trust and personality characteristics have been conducted in developed countries. A very little research if ever conducted is related to developing countries, which cannot truly represent the attitudinal and behavioral dynamics of developing countries. The economic condition, societal development and political factors in developing countries significantly differ from that of developed countries. All these factors affect attitudes and behaviors of the people.

The present study is to be conducted in Pakistan. Being a developing country, it has different economic, societal, cultural and political dynamics affecting peoples' attitudes and behaviors. The discouraging economic conditions, absence of good governance indicators, disturbed law and order situation have resulted in uncertain market conditions. All these factors also shape peoples' attitudes and behavior differently towards businesses and services. Though both goods and services industries are affected by peoples' attitudes and behavior shaped by uncertain economic, societal and political factors, yet the services get the worst. This is because of their peculiar characteristics of perishability, intangibility and irreversibility. People behave more cautiously while going for services after having ascertaining certain aspects which may not be done so rigorously in case of buying goods. The success and competitiveness of services also depend upon the capability of service providers in designing and executing services and maintaining customers' confidence by properly managing all the dimensions of services.

Services industry as a whole is very significant in improving peoples' life style and sharing government's burden, yet certain services are thought of as optional unlike medical and education. For purchasing of insurance policy, people go for services provider with more established reliability (Boyd et al., 2011). They prefer more customized offers and interested in individualized attention and counseling. This is because people are going to invest which can only be repaid in the case of untoward incidents. The importance of credibility, reliability and serviceability of the service provider further increases manifolds in uncertain economic, societal and political conditions, the one like in Pakistan. In developing countries like Pakistan insurance sector plays a vital role in promotion of financial system. The stability of insurance sector is indispensable for mobilization of long term savings and for compensating various losses arising due to uncertainties. Insurance companies may not produce effective results because of fluctuations in equity and real estate prices. Among all insurers, life insurers would be particularly exposed to these variations (Aslam, 2000). The life insurance market should be emphasized because of its rapid growth. Insurance business is becoming global very speedily.

The researcher opines that people's tendency towards demanding customized services and individualized attention, their abilities to trust and be trusted and parameters to judge reliability and ability of the service provider to deliver up to commitments is varying from individual to individual owing to personality dispositions of customer. The one and standard solution for people with different personality characteristics targeted for highly optional service such as insurance policy by not considering their risk taking/risk averting, trusting (extraversion) tendencies may not work well in building customers' trust. So this study will investigate the impact of different dimensions of service quality on trust under the influence of five personality traits.

\subsection{LITERATURE REVIEW}

Services are different from goods due to certain unique characteristics such as intangibility, heterogeneity, inseparability, simultaneous production and consumption, and perishability. Regan (1963) defines services as activities, benefits or satisfaction which are offered for sale or provided in connection with the sale of goods". Tangibility is the mean of differentiating the good and service (Levitt, 1981). Due to intangibility, perception of services by consumer is difficult to understand (Zeithaml et al., 1981). Services are simultaneously produced and consumed and can't be stored as goods (Zeithaml et al., 1985; Onkvisit \& Shaw, 1991). Services are highly variable in terms of delivery as the same service by two different individuals varies, which make them more heterogeneous as compared to goods (Zeithaml et al., 1985; Onkvisit and Shaw, 1991). Services are time dependent which makes it perishable (Onkvisit \& Shaw, 1991). These characteristics of services make them more critical in terms of understanding and delivering quality service to customers (Parasuraman et al., 1985). For this problem, Parasuraman et al. (1985) being pioneer proposes a conceptual model of measuring the service quality known as SERVQUAL. This model helps in measuring the quality of service. It conceptualized service quality as the difference between expectations and perceptions about the service. Expectations are prior to the consumption whereas perception is after the service is delivered. It is the gap between the perceived and the expected services. Customers evaluate the quality of service with their expectations as a reference point (Woodruff et al., 1983; Day, 1977). When the organizations know how (the service) will be evaluated by the customers, they will be able to suggest how to influence these evaluations in a desired direction (Gronroos, 1990). Parasuraman et al. (1988) identified five dimensions of service quality namely reliability, assurance, responsiveness, empathy and tangibility. Reliability is the ability to perform the service accurately as promised (Zeithaml et al., 1990). It can be defined as "degree to which the firm's offering is reliable, standardized, and free from deficiencies" (Fomell et al., 1996). According to Norman (1984), "reliability is performing the promised service dependably and accurately'. Assurance is related to the courtesy and knowledge of the employees in order to covey confidence and trust (Zeithaml et al., 1990). It is the ability of service personnel to convey confidence to customers. In services it refers to the design and process of service delivery which convey confidence. As services are intangible in nature, customers always assure its purchase through expert opinion and from other sources in order to minimize risk (Goldsmith et al., 1994). Responsiveness is the willingness of the service provider to give prompt service and help the customers (Zeithaml et al., 1990). Kelleher and Miller (2006) defined responsiveness as the organizations' willingness to respond promptly to customers' inquiries and complaints." According to Davis 
(1982), responsiveness may be thought of as the probability to which each partner responds to the other, the proportion of relevant responses, and responses that match the demand for appropriate elaboration that the speaker intended to elicit. empathy is the individualized attention given by the service provider to show caring attitude. Customers need attention and when they get individualized attention they feel relaxed (Baumann et al., 2006). For a successful selling, empathy plays a vital role (Kirkpatrick \& Russ, 1976). Empathy helps in creating strong relationships with the customers, better understanding of the customers' needs and predicting their behavior (Redmond, 1989). Customers can be motivated by social motives which can be created by empathy. Tangibility is the appearance of equipment, infrastructure, personnel and any other material through which customers interact (Zeithaml et al., 1990). There is a significant effect of tangibles surround the services on behavioral intentions of customers (Wakefield \& Boldgett, 1999).

According to Morgan and Hunt (1994), trust is the confidence of one party over another in an exchange relationship. It is one's confidence on reliability and consistency of the other. It is the confidence and willingness of one party over another (Moorman et al., 1992). Existence of sufficient confidence on partner's integrity and reliability creates trust (Crosby et al., 1990; Morgan and hunt, 1994; Palmatier et al., 2006). Trust is "a willingness to rely on an exchange partner in whom one has confidence" (Moorman et al., 1992). According to Sirdeshmukh et al., (2002), trust is "the expectations held by the consumers that the service provider is dependable and can be relied upon to deliver on its promises". It is the belief that the service provider (seller) will fulfill its promises (Anderson \& Narus, 1990) and obligations (Dwyer et al., 1987). It is the expectations of customers regarding the company's deliverables (Anderson \& Narus, 1990). According to Agustin and Singh (2005), trust is the consumers' confident belief that he or she can rely on the sellers to deliver promised services. Trust plays a very important role when there is lack of familiarity with the object. It is a strong competitive advantage for a firm in the market and serves as an important asset for the firm (Seemann et al., 2000). Trust is an important component in every transaction for a strong relationship (Couch \& Johnes, 1997). It reduces uncertainty and generates long term relationships with the service provider (Hausman, 2001). Due to the intangible nature of services, it is difficult for the customer to trust on service provider (Levitt, 1983). Service providers try to reduce this effect through tangibles like physical evidence e.g. equipment, building, infrastructure etc. Through these tangibles customer can predict about the quality of service. Trust reduces the threat of being exploited and increases the perception about certainty of other's behavior (Zand, 1972). Sustainability and certainty in relationship with customer comes from trust (Urban et al., 2000). Favorable perception of service quality by customer would be positively associated with customers' trust (Eisingerich \& Bell, 2008). Service quality has a positive and significant relationship with trust (Chiou \& Droge, 2006; Sharma \& Patterson, 1999). Service firms will cultivate trusting relationships when it meets or exceeds customer expectations (Eisingerich \& Bell, 2008). More the empathic and responsive behavior of employees at service counters, more effective and trusting relationships will be there with the customers.

In social psychology, personality has gained focus of psychologist since beginning of the research. This is the firm belief of theorist of personality that personality predicts behavior. Personality directs different aspects of consumer behavior (Solomon, 2002) and helps predicts behavior (Funder \& Colvin, 1991). Personality effects behavior constantly as it is a stable predisposition. Individual behavior is derived from its personality i.e. the actions of an individual is the reflection of its personality (Fleeson, 2001). The most important and widely used theory among personality theories is the trait theory (Chen and Chang, 1989; Endler and Rosenstein, 1997). It based upon the stable predispositions known as individuals' traits. Each individual is different from other on the basis of these traits. Each individual have one trait which is dominant and dictates the behavior of that individual (Fleeson, 2004). Major contribution in the research of personality is done by Costa and McCare (1988) which give Big Five Model of personality. Five-factor model has been widely accepted and used in marketing in cross cultural applications (Caprara et al., 1998; Prue et al., 2015). This model gives five different personality traits which are Conscientiousness, Extraversion, Agreeableness, Neuroticism and Openness to experience. Extraversion personality trait individuals are sociable, gregarious. Their social skill advantage makes them efficient in obtaining information regarding their benefits (Raja et al., 2004). Such individuals have positive emotions (Costa \& McCrae, 1992). They have the ability to develop good relationship with others and they show trusts towards others. Because of this they have many friends all around (Watson \& Clark, 1997). These individuals have excellent skill in developing trusting relationship with others and they give good results where trust building is required (Salgado, 1997). Extraversion individuals are positive thinkers and interpret the situation in a positive way. According to Guido et al., (2007), extraverts' behavior tended to hedonic in nature, which means they give positive meanings to the situation in hand. In addition, Matzler et al. (2006) found the positive relationship between extraversion and positive attitude of an individual about the perception of quality. Individuals having conscientiousness personality trait are strict followers of rules and regulation. They are obedient in nature. They are risk-averse people and always resist the change. They are reliable a well as loyal people (Goldberg, 1990). The commitment and involvement of these individuals towards goals is very high. If things are going according to rules and regulation then satisfaction level of conscientious individual is very high as compared to other personality traits (DeNeve \& Cooper, 1998). The focus of conscientious individual is on outcome which makes their perception positive. According to DeNeve and Cooper (1998) "Agreeableness involves getting along with others in pleasant, satisfying relationship." These individuals are undemanding, kind and sympathetic (Goldberg, 1993). These individuals are easily satisfied with others as their nature is undemanding (Costa \& McCrae, 1988). They always have positive perception about others. They always try to help others as they are kind and sympathetic in nature and also expect the same from other side (Costa \& McCrae, 1992). They are very flexible in nature and adopt things according to the situation. Such individuals handle the conflicting situation very well and try to minimize the tension (Costa \& McCrae, 1992). As they are kind in nature, so they easily neglect the mistakes of others. Their tendency to trust on others is very high (Barrick \& Mount, 1991). They are optimistic in nature and focus on the positive side only. Individuals having openness to experience trait have great interest in innovation and arts (Feist, 1998). De Neve and Cooper (1998) describe as "openness to experience is a double edged sword that predisposes individual to feel both the good and more deeply". They experience things in a different way and their perception differs from others. They are optimistic in nature. They have high emotional attachment as compared to other personality types. Individuals having neurotic personality have negative thinking. Such individual always focus on the dark side. Such individual is submissive in nature and not easily pleased by anyone. Anything goes against $\mathrm{m}$ makes them depress. The high tendency of negative thinking creates negative perception about things (Magnus et al., 1993). Such negative perception creates strong reaction when they find any discrepancy. They are very sensitive in nature which makes them very reactive on even small things (Emmons et al., 1985). As these individuals have negative perceptions and these negative perceptions generate dissatisfaction (Connolly \& Viswevaran, 2000). Such individuals lack interpersonal skills and their tendency to trust on others is very low (Judge et al., 2000). Figure 1 shows the theoretical framework of the study. Our research hypothesis is that personality traits 
moderate the relationship between service quality dimensions and customers' trust. Based on the aforementioned research hypothesis, 25 null hypotheses were developed and tested accordingly.

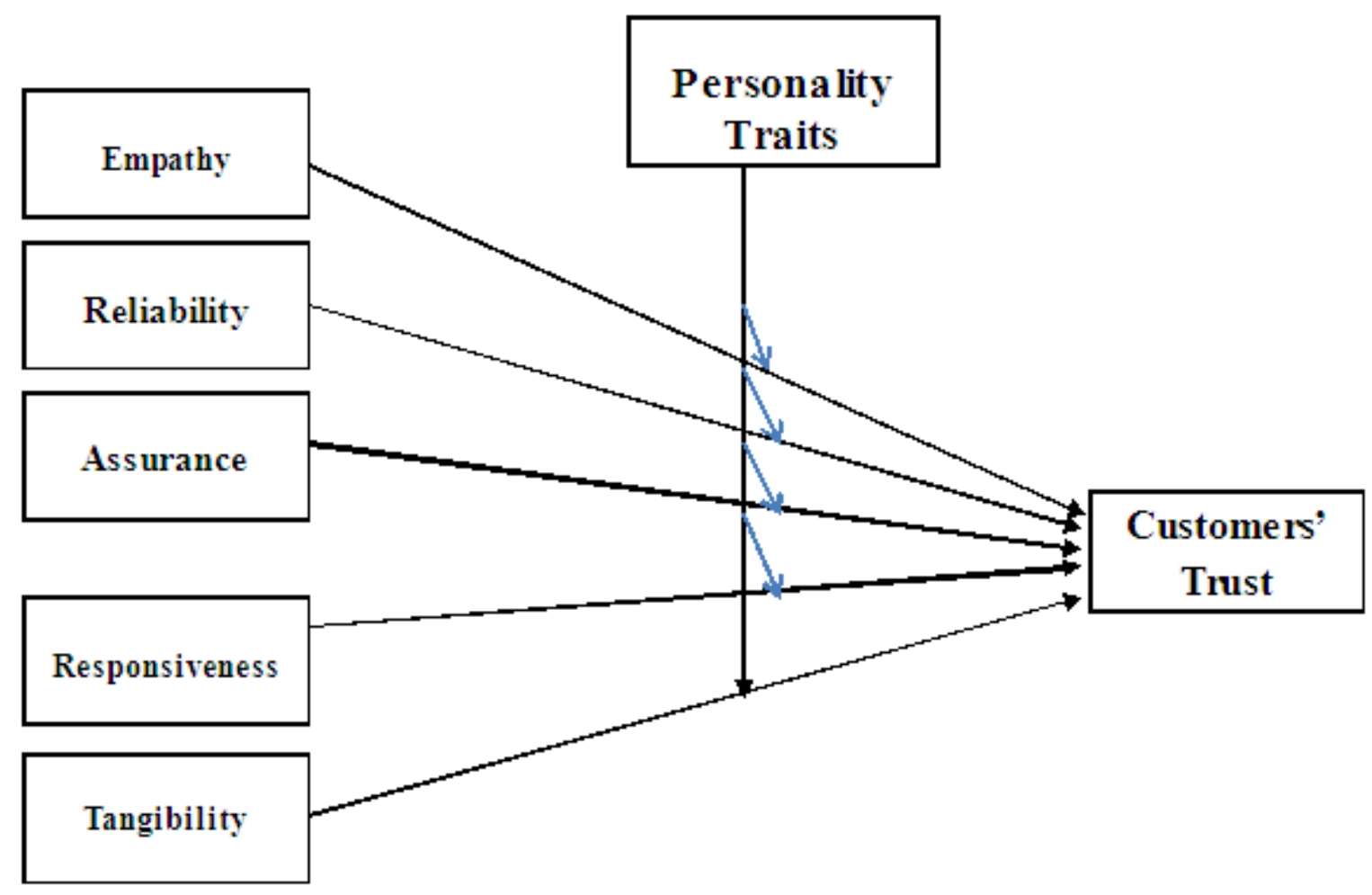

Figure 1 Theoretical framework of the research study

RH: Personality traits moderate the relationship between service quality dimensions and customers' trust.

\subsection{METHODOLOGY}

This research is aimed at investigating the Dimensions of service quality i.e. reliability, assurance, responsiveness, empathy and tangibility, trust and the moderating role of personality traits i.e. extraversion, agreeableness, conscientiousness, openness and neuroticism. For this, current research selects the best method available in order to find out the predicted relationship between variables. This study used selfadministrated field survey, which is most commonly used for quantitative research (Shaughnessy \& Zechmeister, 1985). In order to find out causal relationship between variables, current study used cross sectional filed design. In cross sectional research, researcher will collect data at time one only (Shaughnessy \& Zechmeister, 1985). Present research selected insurance sector operating in Pakistan. Currently, insurance sector have three million customers in Pakistan. Thus, Sample size for this current study uses Israel (1992) method i.e. for $\pm 7 \%$ precision level 204 is the minimum requirement of sample size from a population of 3 million. So, for this study the sample size was 242 which will sufficient enough for representing the population as recommend by Israel (1992). Random sampling technique was used to select the respondent. Data was collected from the major cities of Pakistan. 5-point likert-scale was used for measuring perceived service quality, personality traits and trust ranging from 1 to 5 where 1 shows strongly disagree, 2 shows disagree, 3 shows neither agree nor disagree, 4 shows agree and 5 shows strongly agree. Big Five Inventory (BFI) developed by John and Srivastava, (1999) was used to measure personality traits, Neuroticism (N), Extraversion (E), Conscientiousness (C), Agreeableness (A) and Openness to experience (O) was measured with $8,8,9,9,10$ items respectively. "Servqual", a well-established instrument, developed by Parasuraman et al., (1988) was used to measure dimensions of service quality i.e. tangibility, reliability, responsiveness, assurance and empathy with 4, 5, 4, 4, 5 items respectively. Trust was measured with 4 item scale developed by Morgan and Hunt (1994). In Pakistan English is used as official language so there is no language barrier and respondents can easily understand English. Different researches have been done in Pakistan which used English as medium of instruction (Raja, et al., 2004; Abbas et al., 2012; Bouckenooghe et al., 2013). 25 null hypotheses were developed for moderation between the dimensions of service quality and customers' trust with the moderating role of personality traits. The current study used descriptive statistics, correlation and regression for data analysis. Barron and Kenny (1986) approach was used to test the moderation. 


\subsection{RESULTS AND DISCUSSION}

Demographic analysis reveals that most of the respondents were male 203 (83.9\%), with only 39 (16.1\%) females. 102 (42\%) respondents were falling between 21-30 years age group, 86 (35.5\%) fall between 31-40 years, 37 (15\%) and $16(6.6 \%)$ above 51 years old. $123(51 \%)$ respondents hold master degree, $76(31 \%)$ bachelor degree and remaining 18 percent were below bachelor degree. Majority of the respondents were the customers of State Life Insurance Company (47.9\%) which is the market leader in insurance sector of Pakistan. 24\% of the respondents were associated to the second largest player of this sector i.e. EFU Life insurance. Remaining respondents belonged to other companies of insurance sector. The distribution of age, gender, qualification, income and company is shown in Table 1. Factor analysis reveals that all the items belong to the designated dimensions and no item was deleted.

Table 1 Demographic characteristics of the sample

\begin{tabular}{|c|c|c|c|}
\hline & & Frequency & Percentage \\
\hline \multirow{2}{*}{ Gender } & Male & 203 & 83 \\
\hline & Female & 39 & 17 \\
\hline \multirow{5}{*}{ Age } & Less Than 20 & 0 & 0 \\
\hline & $21-30$ & 102 & 42.1 \\
\hline & $31-40$ & 86 & 35.5 \\
\hline & $41-50$ & 37 & 15.3 \\
\hline & 51 and Above & 17 & 7 \\
\hline \multirow{5}{*}{ Qualification } & Matriculation & 9 & 3.7 \\
\hline & Intermediate & 23 & 9.5 \\
\hline & Bachelor & 76 & 31.4 \\
\hline & Master & 123 & 50.8 \\
\hline & Others & 11 & 4.5 \\
\hline \multirow{4}{*}{ Income } & Less Than 20000 & 25 & 10.3 \\
\hline & $20000-40000$ & 102 & 42.1 \\
\hline & $40001-60000$ & 60 & 24.8 \\
\hline & More Than 60000 & 55 & 22.7 \\
\hline \multirow{9}{*}{ Company } & EFU & 58 & 24.0 \\
\hline & State Life & 116 & 47.9 \\
\hline & Adamjee & 11 & 4.5 \\
\hline & American Life & 5 & 2.1 \\
\hline & Jubilee & 23 & 9.5 \\
\hline & East west & 3 & 1.2 \\
\hline & Pak Qatar & 6 & 2.5 \\
\hline & Dawood & 17 & 7.0 \\
\hline & Asia care & 3 & 1.2 \\
\hline
\end{tabular}

High correlation was found between the independent variables (empathy, responsiveness, tangibility, reliability and assurance) and dependent variable i.e. customers' trust. The correlation value between tangibility and customers trust was $\mathrm{r}=.367$ at $\mathrm{p}=.00$, positive and significant. The correlation value between reliability and customers' trust was $\mathrm{r}=.401 \mathrm{at} \mathrm{p}=.000$, positive and significant. The correlation value between responsiveness and customers trust was .371 at $\mathrm{p}=.000$, positive and significant. The correlation value between assurance and customers' trust was $\mathrm{r}=.448$ at $\mathrm{p}=.000$ which shows a strong relationship between the variables. The correlation between empathy and customers' trust was .423 at $\mathrm{p}=.000$. This value shows strong relationship between empathy and customers' trust. 
Table 2 Correlation analysis between the variables\

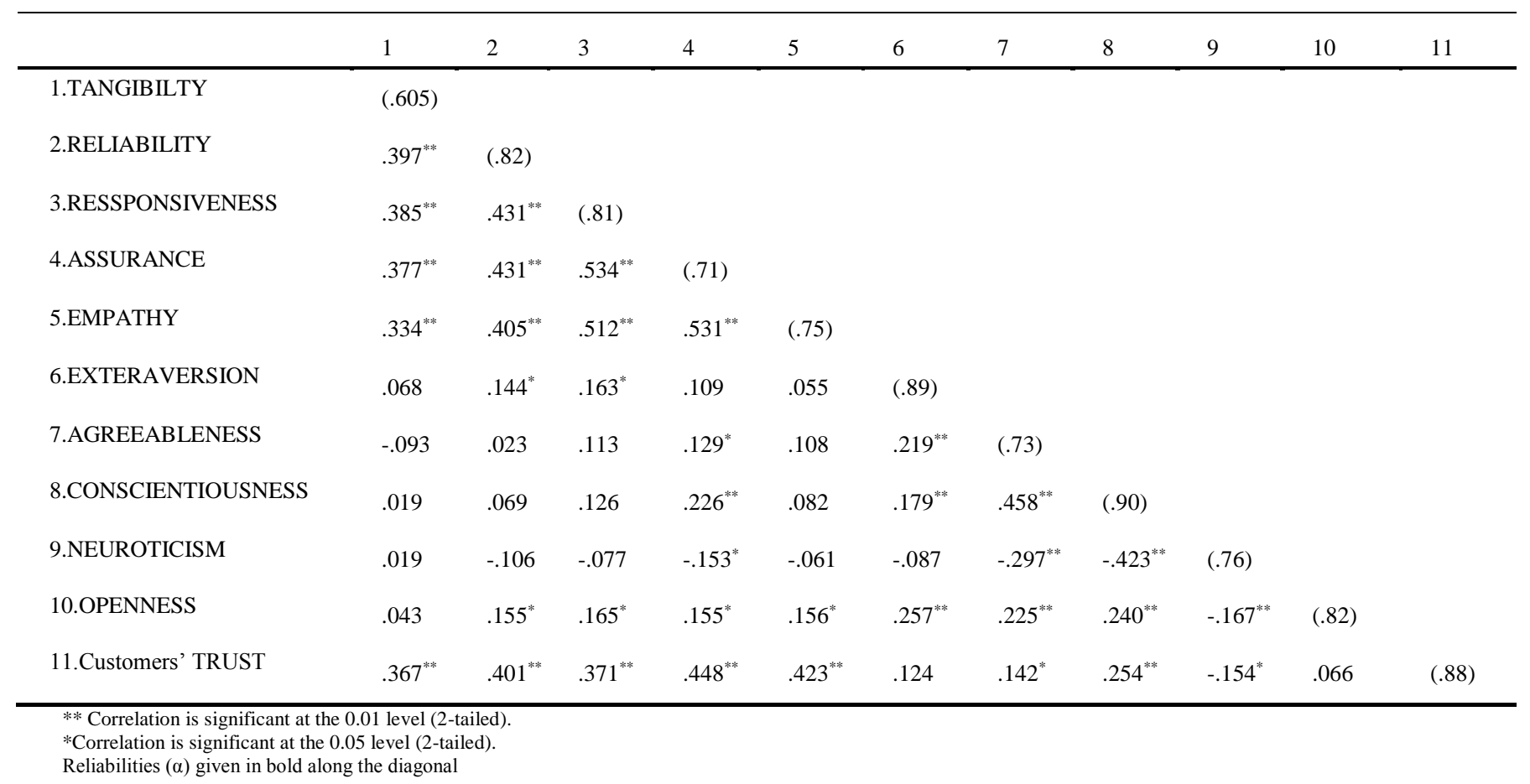

Hierarchical regression was used to test the hypothesis (refer table 3). Regression results between tangibility and customers' trust show significant relationship $(\beta=.118, \mathrm{p}=.017)$, hence accepted H1. Regression results between reliability and customers' trust show significant relationship $(\beta=.163, \mathrm{p}=.013)$, hence supported H2. Regression results between responsiveness and customers' trust show significant relationship $(\beta=.04, \mathrm{p}=.03)$, hence accepted hypothesis H3. Regression results between assurance and customers' trust show significant relationship $(\beta=.201, \mathrm{p}=.004)$, hence accepted H4. Regression results between empathy and customers' trust show significant relationship ( $\beta=.117, \mathrm{p}=.011$ ), hence supported H5. For moderation analysis, Barron and Kenny (1986) method was used to test the 25 hypotheses of moderation which are shown in table 4 . All the hypotheses were accepted.

Table 3 Regression analysis for customers' trust

\begin{tabular}{|c|c|c|}
\hline Predictors & $B$ & $\mathrm{R}^{2}$ \\
\hline Tangibility & $.118 * *$ & \\
\hline Reliability & $.163^{* *}$ & \\
\hline Responsiveness & $.042 *$ & \\
\hline Assurance & $.201 * * *$ & \\
\hline Empathy & $.177 * *$ & .30 \\
\hline
\end{tabular}


Table 4 Moderating role of personality traits with dimensions of service quality \& customers' trust

\begin{tabular}{|l|l|l|l|}
\hline Hypothesis & \multicolumn{2}{|l|}{ IV- Moderator- DV } & $\Delta \mathrm{R}^{2}$ \\
\hline H1 & REL EXT CT & $.053^{* * *}$ & Support \\
\hline H2 & REL AGR CT & $.021^{*}$ & YES \\
\hline H3 & REL CON CT & $.034^{* *}$ & YES \\
\hline H4 & REL NEU CT & $.084^{* * *}$ & YES \\
\hline H5 & REL OPN CT & $.027^{* *}$ & YES \\
\hline H6 & TAN EXT CT & $.092^{* * *}$ & YES \\
\hline H7 & TAN AGR CT & $.024^{* *}$ & YES \\
\hline H8 & TAN CON CT & $.028^{* *}$ & YES \\
\hline H9 & TAN NEU CT & $.048^{* * *}$ & YES \\
\hline H10 & TAN OPN CT & $.017^{*}$ & YES \\
\hline H11 & RES EXT CT & $.018^{*}$ & YES \\
\hline H12 & RES AGR CT & $.021^{*}$ & YES \\
\hline H13 & RES CON CT & $.022^{*}$ & YES \\
\hline H14 & RES NEU CT & $.058^{* * *}$ & YES \\
\hline H15 & RES OPN CT & $.034^{* *}$ & YES \\
\hline H16 & ASS EXT CT & $.019^{*}$ & YES \\
\hline H17 & ASS AGR CT & $.050^{* * *}$ & YES \\
\hline H18 & ASS CON CT & $.039^{* * *}$ & YES \\
\hline H19 & ASS NEU CT & $.043^{* * *}$ & YES \\
\hline H20 & ASS OPN CT & $.046^{* * *}$ & YES \\
\hline H21 & EMP EXT CT & $.022^{* *}$ & YES \\
\hline H23 & EMP AGR CT & $.043^{* * *}$ & YES \\
\hline H24 & EMP CON CT & $.039^{* * *}$ & YES \\
\hline H25 & EMP NEU CT & $.052^{* * *}$ & YES \\
\hline
\end{tabular}

Note: REL=Reliability, ASS=Assurance, RES=Responsiveness, EMP=Empathy, TAN=Tangibility, EXT=Extraversion, AGR=Agreeableness, CT=Customers’ Trust, $\mathrm{CON}=$ Conscientiousness, $\mathrm{NEU}=$ Neuroticism, $\mathrm{OPN}=\mathrm{Openness} \mathrm{to} \mathrm{Experience.}$

\subsection{CONCLUSION}

In this article, the relationship between dimensions of service quality and customers' trust under the influence of personality traits was investigated which provides useful insights for how service provider should allocate resources in different personality groups. Relative importance of dimensions of service quality in relation with customers' trust in insurance sector of Pakistan was shown where assurance comes on the higher end and tangibility comes at the lower end and in between is empathy, reliability and responsiveness respectively, consistent with the results of Kassim and Abdullah (2010). According to Mattila (1999), culture has a significant impact on the evaluation of complex services. This study was conducted in Pakistan, where power distance, uncertainty avoidance and masculinity indexes are high, customers expect extremely good treatment and attach greater importance to responsiveness, reliability, assurance tangibility and empathy. Furrer and Sudharshan (2000) examined and explore that in high power distance and high masculinity culture customers give significant importance to responsiveness, reliability, assurance tangibility and empathy. Mattila (1999) in a similar manner concluded that in cultures characterized by large power distance, service employees requires them to provide customers with a high level of service. In addition, this study develops complete set of hypotheses relating each personality trait and each dimension of service quality with customers' trust. Results show that all the hypotheses are supported (refer table 3).

The results of the study can used to segment market according to the personality traits because the perception of service quality in each personality trait is different. This challenge of segmentation can be counter by facilitating the process of segmentation in the light of personality traits. Such a segmentation scheme allows service marketers to define marketing objectives more precisely and have better understanding of customer needs. In each segment, the focus could be made on the most important service quality dimensions and resources could be allocated proportionally to the relative importance of each dimension. This article is subject to a few limitations. In our empirical study, only one sector was surveyed i.e. insurance sector of Pakistan. Other sectors need to be tested in future research to make it generalize. To do so, different types of services like banking, health and hotel have to be surveyed. Changes in service expectations demand longitudinal research as this study have a limitation of cross sectional research design. Future research can enhance the understanding by adding dependent variables like loyalty and WOM.

\section{References}

Abbas, M., Raja, U., Darr, W., \& Bouckenooghe, D. (2014). Combined Effects of Perceived Politics and Psychological Capital on Job Satisfaction, Turnover Intentions, and Performance. Journal of Management, 40(7), 1813-1830.

Agustin, C. \& Singh, J. (2005). Curvilinear Effects of Consumer Loyalty Determinants in Relational Exchanges. Journal of Marketing Research. 42(1), 96-108.

Anderson, J. C. \& Narus, J. A. (1990). A Model Of Distributor Firm and Manufacturer Firm Working Partnerships. Journal of Marketing. 54, 42-58.

Barrick, M. R. \& Mount, M. K. (1991). The Big Five Personality Dimensions and Job Performance: A Meta-Analysis. Personnel Psychology. 44, 1-26.

Baumann, C., Burton, S., Elliott, G., \& Kehr, H. M. (2006). Prediction of Attitude and Behavioral Intentions in Retail Banking. International Journal of Bank Marketing. 25(2), 102-116.

Bouckenooghe, D., Raja, U., \& Butt, A. N. (2013). Combined Effects of Positive and Negative Affectivity and Job Satisfaction on Job Performance and Turnover Intentions. The Journal of Psychology, 147(2), 105-123.

Boyd, M., Pai, J., Zhang, Q., Holly Wang, H., \& Wang, K. (2011). Factors Affecting Crop Insurance Purchases in China: The Inner Mongolia Region. China Agricultural Economic Review, 3(4), 441-450. 
Chen, Z. G. \& Chang, Y. X. (1989). Psychology of Personality. (1 ${ }^{\text {st }}$ ed.). Wu-Nan Book Inc., Taipei.

Chiou, J. \& Cornelia Droge. (2006). Service Quality, Trust, Specific Asset Investment, and Expertise: Direct and Indirect Effects in a Satisfaction-Loyalty Framework. Journal of the Academy of Marketing Science. 34, 613-627.

Connolly, J. J., \& Viswesvaran, C. (2000). The Role of Affectivity in Job Satisfaction: A Meta-analysis. Personality and Individual Differences. 29, 265-281

Costa, P. T. \& McCrae, R. R. (1988). Personality in Adulthood: A Six-Year Longitudinal Study of Self-Reports and Spouse Ratings on the Neo Personality Inventory. Journal of Personality and Social Psychology. 54, 853-863.

Costa, P. T. \& McCrae, R. R. (1992). Professional Manual: Revised Neo Personality Inventory (Neo-Pi-R) and Neo Five-Factor Inventory (Neo-Ffi). Odessa, FL: Psychological Assessment Resources.

Couch, L. L. \& Jones, W. H. (1997). Measuring Levels of Trust. Journal of Research in Personality. 31, 319-336.

Crosby, L. A., Evans, K. E. \& Cowles, D. (1990). Relationship Quality in Services Selling: An Interpersonal Influence Perspective. Journal of Marketing. 54, 68-81.

Davis, D. (1982). Determinants of Responsiveness in Dyadic Interaction. Personality, Roles, and Social Behavior. (pp. 85-139). New York, NY: Springer-Verlag.

DeNeve, K. M. \& Cooper, H. (1998). The Happy Personality: A Meta-analysis of 137 Personality Traits and Subjective Well-being. Psychological Bulletin. 124, 197229.

Dwyer, F. R., Schurr, P. H. \& Oh, S. (1987). Developing Buyer-Seller Relationships. Journal of Marketing. 51(2), 11-27.

Eisingerich, A. B. \& Bell, S. J. (2008). Perceived Service Quality and Customer Trust: Does Enhancing Customers' Service Knowledge Matter? Journal of Service Research. 10(3), 256-68.

Emmons, R. A., Diener, E. \& Larsen, R. J. (1985). Choice of Situations and Congruence Models of Interactionism. Personality and Individual Differences. 6, 693-702.

Endler, N. S., \& Rosenstein, A. J. (1997). Evolution of the Personality Construct in Marketing and its Applicability to Contemporary Personality Research. Journal of Consumer Psychology, 6(1), 55-66.

Feist, G. J. (1998). A Meta-analysis of Personality in Scientific and Artistic Creativity. Personality and Social Psychology Review. 2(4), 290-309.

Fleeson, W. (2001). Towards a Structure and Process-integrated View of Personality: Traits as Density Distributions of States. Journal of Personality and Social Psychology. 80, 1011-1027.

Fleeson, W. (2004). Moving Personality Beyond the Person-situation Debate: The Challenge and the Opportunity of Within-person Variability. Current Directions. $13,83-87$.

Fornell, C., Johnson, M. D., Anderson, E. W., Cha, J., \& Bryant, B. E. (1996). The American Customer Satisfaction Index: Nature, Purpose, and Findings. Journal of Marketing, 60(4), 7-18.

Funder, D. C. \& Colvin, C. R. (1991). Explorations in Behavioral Consistency: Properties of Persons, Situations, and Behaviors. Journal of Personality and Social Psychology. 60, 773-794.

Furrer, O., Liu, B. S. C., \& Sudharshan, D. (2000). The Relationships between Culture and Service Quality Perceptions Basis for Cross-cultural Market Segmentation and Resource Allocation. Journal of Service Research, 2(4), 355-371.

Goldberg, L. R. (1990). An Alternative "Description of Personality": The Big-Five Factor Structure. Journal of Personality and Social Psychology, 59 (6), 1216.

Goldsmith, R. E., Flynn, L. R., \& Bonn, M. (1994). An Empirical Study of Heavy Users of Travel Agencies. Journal of Travel Research, $33(1)$, 38-43.

Gronroos, C. (1990). Service Management: A Management Focus for Service Competition. International Journal of Service Industry Management, 1(1), 6-14.

Guido, G., Capestro, M., \& Peluso, A. M. (2007). Experimental Analysis of Consumer Stimulation and Motivational States in Shopping Experiences. International Journal of Market Research, 49(3), 365.

Hausman, A. (2001). Variations in Relationship Strength and its Impact on Performance and Satisfaction in Business Relationships. Journal of Business \& Industrial Marketing. 1(7), 600-16.

Heskett, J. L., Jones, T. O., Loveman, G. W., Sasser, W. E. \& Schlesinger, L. A. (1994). Putting the Service-profit Chain to Work. Harvard Business Review. 72, 16474.

Israel, G. D. (1992). Determining Sample Size. IFAS Extension, University of Florida. PEOD6.

John, O. P. \& Srivastava, S. (1999). The Big Five Trait Taxonomy: History, Measurement, and Theoretical Perspectives. Handbook of Personality: Theory and Research. . 102-138. New York: Guilford Press.

Johnson, M. D. \& Lars, N. (2001). The Importance of Reliability and Customization from Goods to Services. Quality Management Journal. 8(1), 8-19.

Judge, T. A. \& llies, R. (2002). Relationship of Personality to Performance Motivation: A Meta-analytic Review. Journal of Applied Psychology. 85, 751-765.

Kassim, N., \& Abdullah, N. A. (2010). The Effect of Perceived Service Quality Dimensions on Customer Satisfaction, Trust, and Loyalty in E-commerce Settings: A Cross Cultural Analysis. Asia Pacific Journal of Marketing and Logistics, 22(3), 351-371.

Kelleher, T. \& Miller, B. M. (2006). Organizational Blogs and the Human Voice: Relational Strategies and Relational Outcomes. Journal of Computer-Mediated Communication. 11(2), 395-414.

Levitt, T. (1981). Marketing Intangible Products and Product Intangibles. Harvard Business Review. 81, 94-102.

Lin, L.Y. (2010). The Relationship of Consumer Personality Trait, Brand Personality and Brand Loyalty: An Empirical Study of Toys and Video Games Buyers. Journal of Product \& Brand Management, 19 (1), 4-17.

Magnus, K., Diener, E., Fujita, F. \& Pavot, W. (1993). Extraversion and Neuroticism as Predictors of Objective Life Events: A Longitudinal Analysis. Journal of Personality and Social Psychology. 65, 1046-1053.

Mattila, A. S. (1999). The Role Of Culture in the Service Evaluation Process. Journal of Service Research, 1(3), $250-261$.

Matzler, K., Bidmon, S. \& Grabner-Kräuter, S. (2006). Individual Determinants of Brand Affect: The Role of the Personality Traits of Extroversion and Openness to Experience. Journal of Product \& Brand Management, 15(7), 427-434.

Moorman, C., Zaltman, G. \& Deshpande', R. (1992). Relationships between Providers and Users of Market Research: The Dynamics of Trust Within and Between Organizations. Journal of Marketing Research. 29, 314-28.

Morgan, R. M. \& Hunt S. D. (1994). The Commitment-trust Theory of Relationship Marketing. Journal of Marketing. 58, 20-38.

Norman, R. (1984). Service Management Strategy and Leadership. Wiley, New York.

Onkvisit, S. \& Shaw, J. J. (1991). Is Services Marketing "Really” Different? Journal of Professional Services Marketing. 7(2), 3-17.

Palmatier, R. W., Dant, R. P., Grewal, D. \& Evans, K. R. (2006). Factors Influencing The Effectiveness of Relationship Marketing: A Meta-Analysis. Journal of Marketing. 70, 136-53.

Parasuraman, A., Leonard L. Berry, \& Valarie A. Zeithaml. (1991b). Understanding, Measuring and Improving Service Quality: Findings from a Multiphase Research Program. In Brown, S. W., Gummesson, E., Edvardson, B. and Gustavsson, B. (Eds.) Service Quality: Multidisciplinary and Multinational Perspectives. 251-268. New York: Lexington Books.

Parasuraman, A., Valarie A. Zeithaml, \& Leonard, L. Berry. (1985). A Conceptual Model of Service Quality and its Implications for Future Research. Journal of Marketing. 49, 41-50

Parasuraman, A., Valarie, A., Zeithaml \& Leonard, L. Berry. (1988). SERVQUAL: A Multiple Item Scale for Measuring Consumer Perceptions of Service Quality. Journal of Retailing. 64(1), 12-40.

Prue, B., Stern, L. D., Hurley, P., Catto, G., Young, D., \& Pfautz, J. (2015). Application of Personality Theories for the Design and Development of Cross-cultural Decision-making Tools. Procedia Manufacturing, 3, 4006-4013.

Raja, U., Johns, G. \& Ntalianis, F. (2004). The Impact of Personality on Psychological Contracts. Academy of Management Journal. 47, $350-367$.

Rathmell, J. M. (1966). What is Meant by Services? Journal of Marketing. 30, 32-36.

Redmond, Mark V. (1989). The Functions of Empathy (Decentering) in Human Relations. Human Relations. 42, 593-605

Regan, W. J. (1963). The Service Revolution. Journal of Marketing. 47, 57-62.

Rust, Roland T., Katherine N. L, \& Valarie A. Z. (2004). Return on Marketing: Using Customer Equity to Focus Marketing Strategy. Journal of Marketing, 68, 109127. 
Rust, Roland T., Christine Moorman, \& Peter R. Dickson (2002). Getting Return on Quality: Revenue Expansion, Cost Reduction, or Both? Journal of Marketing, 66, $7-24$.

Salgado, J. F. (1997). The Five Factor Model of Personality and Job Performance in the European Community. Journal of Applied Psychology. 82, 30-43.

Seemann, P., De Long, D., Stucky, S. \& Guthrie, E. (2000). Building Intangible Assets: A Strategic Framework for Investing in Intellectual Capital. In Morey, D., Maybury, M. and Thuraisingham, B. (Eds.) Classics Knowledge Management. 85-98. MIT (Massachusetts Institute for Technology), (T1).

Shaughnessy, J. J., \& Zechmeister, E. B. (1985). Research Methods in Psychology. Alfred A.Knopf.

Sirdeshmukh, D., Singh, J. \& Sabol, B. (2002). Consumer Trust, Value, and Loyalty in Relational Exchanges. The Journal of Marketing. 66, 1, 15-37.

Solomon, M. R. (2002). Consumer Behavior: Bying, Having, Being. (5 ${ }^{\text {th }}$ ed.). Upper Saddle River, New Jersey.

Urban, G. L., Sultan, F. \& William J. Q. (2000). Placing Trust at the Center of your Internet Strategy. Sloan Management Review. 42, 39-49.

Wakefield, K. L. \& Blodgett, J. G. (1999). Customer response to Intangible and Tangible Service Factors. Psychology and Marketing. 16(1), 51-68.

Watson, D. \& Clark, L. A. (1997). Extraversion and its Positive Emotional Core. In Hogan, R., Johnson, J. A. and Briggs, S. R. (Eds.) Handbook of Personality Psychology. (pp. 767-793). San Diego: Academic Press.

Woodruff, R. B., Ernest, R., Cadotte, \& Roger, L. J. (1983). Modeling Consumer Satisfaction Processes using Experience-based Norms. Journal of Marketing Research. 20, 296-304.

Zand, E. D. (1972). Trust and Managerial Problem Solving. Administrative Science Quarterly. 17, 229-239.

Zeithaml, A. V., Berry, L. L. \& Parasuraman, A. (1981). How Consumers' Evaluation Processes Differ between Goods and Services. Marketing of Services. 186-190.

Zeithaml, A. V., Berry, L. L. \& Parasuraman, A. (1996). The Behavioral Consequences of Service Quality. Journal of Marketing. 60, 31-46.

Zeithaml, A. V., Parasuraman, A. \& Berry, L. L. (1990). Delivering Quality Service: Balancing Customer Perceptions and Expectations. New York: The Free Press.

Zeithaml, V. A., Parasuraman, A. \& Berry, L. L. (1985). Problems and Strategies in Services Marketing. Journal of Marketing. 49, 33-46. 